\title{
Modeling study of gamma oscillations in the mammalian olfactory bulb \\ Nicolas Fourcaud-Trocmé1,2,3
}

\begin{abstract}
Address: ${ }^{1}$ Université de Lyon, Lyon, F-69366, France, ${ }^{2}$ Université Lyon 1, Lyon, F-69366, France and ${ }^{3}$ CNRS, UMR5020, Neurosciences sensorielles comportement cognition, France

Email: Nicolas Fourcaud-Trocmé - nfourcau@olfac.univ-lyon1.fr
\end{abstract}

from Eighteenth Annual Computational Neuroscience Meeting: CNS*2009

Berlin, Germany. 18-23 July 2009

Published: I 3 July 2009

BMC Neuroscience 2009, I0(Suppl I):P264 doi:I0.I I86/I47|-2202-I0-SI-P264

This abstract is available from: http://www.biomedcentral.com/I47I-2202/I0/SI/P264

(C) 2009 Fourcaud-Trocmé; licensee BioMed Central Ltd.

\section{Introduction}

The dynamics of the mammalian olfactory bulb (OB) are characterized by local field potential oscillations that are either slow, in the theta range $(2-10 \mathrm{~Hz}$, tightly linked to the respiratory rhythm), or fast, in the beta $(15-30 \mathrm{~Hz})$ or gamma $(40-90 \mathrm{~Hz})$ range. Despite that these fast oscillations have been known for a long time and have been shown to be modulated by odorant features [1] and animal experience or state $[2,3]$, both their mechanisms and implication in coding are still not well understood. In this study, we focused on the underlying dynamics generating the gamma oscillations. These oscillations have been shown to be generated intrinsically to the $\mathrm{OB}$ in response to strong excitation of the olfactory sensory neurons [4]. Moreover experimental [5] and modeling [6] studies have shown that they are generated by the interplay between excitatory mitral cells and inhibitory granule cells. However, existing models do not take into account the recently discovered columnar organization of the OB [7]. In this study, we show how this organization may account for a local generation of gamma oscillations by the strongest activated glomeruli in a very specific frequency range and how this oscillation can then entrain mitral cells linked to less activated glomeruli.

\section{Methods and results}

A model of a single glomerular column including simple models of mitral and granule cells has been constructed (similar to [6]). Simulations of this model have been performed using the open source simulator BRIAN [8]. This model can generate oscillations in a wide range of fre- quency $(20-100 \mathrm{~Hz})$ depending on its stimulation strength (excitation of mitral cells). However, the frequency of gamma oscillations recorded in vivo is restricted to a very narrow range: $60-70 \mathrm{~Hz}$. We searched for which model aspects could constrain the oscillations in such a range. We took into account the strong intraglomerular mitral to mitral excitatory connections (see for example [9]) and show how for a wide range of input strengths, they can put the model in a high activation state leading to oscillations in the experimentally observed gamma range. Finally, we completed this model by adding other similar glomerular columns and tested how the strongest activated columns could entrain the other into the gamma oscillation.

\section{References}

I. Cenier T, Amat C, Litaudon P, Garcia S, Lafaye de Micheaux P, Liquet $B$, Roux S, Buonviso N: Odor vapor pressure and quality modulate local field potential oscillatory patterns in the olfactory bulb of the anesthetized rat. Eur J Neurosci 2008, 27: I 432-1440.

2. Freeman WJ, Schneider W: Changes in spatial patterns of rabbit olfactory EEG with conditioning to odors. Psychophysiology 1982, 19:44-56.

3. Ravel N, Chabaud P, Martin C, Gaveau V, Hugues E, Tallon-Baudry C, Bertrand $O$, Gervais R: Olfactory learning modifies the expression of odour-induced oscillatory responses in the gamma $(60-90 \mathrm{~Hz})$ and beta $(15-40 \mathrm{~Hz})$ bands in the rat olfactory bulb. Eur J Neurosci 2003, 17:350-358.

4. Neville KR, Haberly LB: Beta and gamma oscillations in the olfactory system of the urethane-anesthetized rat. I Neurophysiol 2003, 90:3921-3930.

5. Lagier S, Carleton A, Lledo P: Interplay between local GABAergic interneurons and relay neurons generates gamma oscillations in the rat olfactory bulb. J Neurosci 2004, 24:4382-4392. 
6. Bathellier B, Lagier S, Faure P, Lledo P: Circuit properties generating gamma oscillations in a network model of the olfactory bulb. J Neurophysiol 2006, 95:2678-2691.

7. Willhite DC, Nguyen KT, Masurkar AV, Greer CA, Shepherd GM, Chen WR: Viral tracing identifies distributed columnar organization in the olfactory bulb. Proc Natl Acad Sci USA 2006, 103: | 2592-12597.

8. Goodman $D$, Brette R: Brian: a simulator for spiking neural networks in python. Front Neuroinformatics 2008, 2:5.

9. Christie JM, Westbrook GL: Lateral excitation within the olfactory bulb. J Neurosci 2006, 26:2269-2277.

Publish with Bio Med Central and every scientist can read your work free of charge

"BioMed Central will be the most significant development for disseminating the results of biomedical research in our lifetime."

Sir Paul Nurse, Cancer Research UK

Your research papers will be:

- available free of charge to the entire biomedical community

- peer reviewed and published immediately upon acceptance

- cited in PubMed and archived on PubMed Central

- yours - you keep the copyright

Submit your manuscript here:

http://www.biomedcentral.com/info/publishing_adv.asp 